\title{
Validity of the Human System Audit Transformational Leadership Short Scale (HSA-TFL) in four european countries
}

\author{
Validez de la escala corta de Liderazgo Transformacional \\ en el marco de la Auditoría del Sistema Humano \\ en cuatro países europeos (HSA-TFL)
}

Recibido: julio 19 de 2010 | Revisado: septiembre 3 de 2010 | Aceptado: septiembre 10 de 2010

\author{
RITA BERgER* \\ MONTSERRAT YEPES \\ JUANA GÓMEZ-BENITO ** \\ SANTIAGO QUiJANO \\ Universidad de Barcelona, España \\ FELIX C. BRODBECK ${ }^{* *}$ \\ Ludwig-Maximillians Universität, München, Alemania
}

SICI: 1657-9267(201112)10:3<657:HSATFL>2.3.TX;2-S

Para citar este artículo. Berger, R., Yepes, M., Gómez-Benito, J., Quijano, S. \& Brodbeck, F. (2011). Validity of the Human System Audit Transformational Leadership Short Scale (HSA-TFL) in four european countries. Universitas Psychologica, 10 (3), 657-668.

* Departamento de Psicología Social, Facultad de Psicología, Passeig Vall d'Hebron, 171, 08035 Barcelona, España. E-mails: ritaberger@ub.edu, myepes@ub.edu,sdiazdequijano@ub.edu

** Departamento de Metodología de las Ciencias del Comportamiento, Facultad de Psicología. Passeig Vall d'Hebron, 171, 08035 Barcelona, España. Instituto de Investigación en Cerebro, Cognición y Conducta (IR3C), Universidad de Barcelona. E-mail: juanagomez@ub.edu

**** Leopoldstraße 13, Zi. 3204, Pf. 1, D-80802 München, Deutschland (Alemania).E-mail: brodbeck@ lmu.de
A B S T R A C T

This study aimed to clarify the validity of the short scale of Transformational Leadership used by the Human System Audit (short HSA-TFL). The need of today's enterprises for combined assessment of transformational leadership and quality-related performance in wider contexts requires short instruments based on scientific research. Convergent, construct and criterion validity of the short HSA-TFL were analyzed. Comparison of the short HSA-TFL with the Multifactor Leadership Questionnaire (MLQ-5X) showed high convergent validity. Exploratory factor analysis with hospital workers in Spain $(N=625)$ showed the single factor structure of the Spanish version of the HSA-TFL. Confirmatory factor analysis using three further samples of hospital workers $(\mathrm{N}=776)$ from different european countries confirmed a single factor. As regards criterion validity, the results indicated that the short HSA-TFL is positively related in all four countries to subjective performance. In sum, the results provide empirical evidence for the validity of the short HSA-TFL scale.

Key words authors

Construct validity, short scale, transformational leadership.

Key words plus

Human relations, leadership, psychometry.

\section{RESU MEN}

La necesidad de las empresas de evaluar el liderazgo transformacional en un contexto amplio y combinado con rendimiento de calidad, requiere instrumentos cortos y, al mismo tiempo, basados en evidencia científica. El objetivo de este estudio fue analizar la validez (convergente, de constructo y de criterio) de la escala corta del Liderazgo Transformacional, usada por la Auditoria del Sistema Humano (short HSA-TFL). La comparación con el Multifactor Leadership Questionnaire (MLQ-5X) aportó valores de alta validez convergente. El análisis factorial exploratorio con empleados del sector sanitario en España $(N=625)$ del HSA-TFL, sugiere una estructura unifactorial, que fue confirmada mediante análisis factorial confirmatorio, realizado con otras tres muestras de empleados del sector hospitalario de varios países europeos $(N=776)$. Asimismo, los resultados muestran, en los cuatro países, una relación positiva del HSA-TFL con el rendimiento 
subjetivo (validez de criterio). En conclusión, la versión breve del HSA-TFL es válida para el análisis del liderazgo transformacional.

Palabras clave autores

Validez de constructo, escala corta, liderazgo transformacional.

Palabras clave descriptores

Relaciones humanas, liderazgo, psicometría.

The concept of transformational leadership is of particular relevance to the enterprises of today's complex world (Jung, Chow \& Wu, 2003). The most well-known operationalization of this concept, the Multifactor Leadership Questionnaire (MLQ), was developed by Bass (1985). However, despite the considerable interest in Bass' transformational leadership (TFL) concept, some aspects have been subject to intense debate. One of the most important of these is the ambiguity concerning the differentiation and number of sub-dimensions of Bass' transformational leadership model. Furthermore, very strong relationships have been reported between the transformational leadership factors (Avolio, Bass \& Jung, 1999; Carless, 1998; Tejeda, Scandura \& Pillai, 2001). Enterprises today have an increased need for combined assessment of leadership and quality-related aspects of performance (Lowe, Kroeck \& Sivasubramaniam, 1996; Molero, Cuadrado, Navas \& Morales, 2007). To meet these needs it is necessary to develop a valid instrument that is easy and quick to apply (Carless, Wearing \& Mann, 2000), based on scientific research (Felfe, 2006) and which leads to recommendations for performance-related development and intervention for leadership in a wider organizational context. This was the main aim of the present study. Following these ideas we consider transformational leadership theory in the interest of today's organizations and conclude that there is a need for a TFL short scale. The short HSA-TFL scale is part of the organizational behavior conceptual framework of the Human System Audit (HSA) (Quijano, 2006).

\section{Transformational leadership theory in the interest of today's organizations}

Bass (1985) based his theory of transformational leadership on Burns's (1978) conceptualization, with several modifications. Following Bass (1985), the four dimensions of transformational leadership are charisma or idealized influence, inspirational motivation, intellectual stimulation, and individualized consideration.

After more than 25 years of accumulated research evidence the effectiveness of transformational leadership is acknowledged throughout the literature. Empirical studies show that transformational facets have a stronger relationship to success and to both individual and organizational outcome criteria (Zhu, Chew \& Spangler, 2005) than do transactional scales (Lowe et al., 1996). Several meta-analyses have also provided evidence for the criterion-related validity of transformational and charismatic leadership (Dumdum, Lowe \& Avolio, 2002; Fuller, Patterson, Hester \& Stringer, 1996; Judge \& Piccolo, 2004), which consistently showed a positive impact on both subjective (Lowe et al., 1996) and objective (Barling, Weber \& Kelloway, 1996; Geyer \& Steyrer, 1998) performance criteria. Transformational leadership behavior has been empirically linked to increased employee (e.g., Podsakoff, MacKenzie, Moorman \& Fetter, 1990) and job satisfaction (Nemanicha \& Seller, 2007), organizational commitment (e.g. Bycio, Hackett \& Allen, 1995), supervisor-rated performance, extra effort (e.g. Seltzer \& Bass, 1990), overall employee (e.g. Yammarino, Spangler \& Bass, 1993) and unit performance (Bass, Avolio, Jung \& Berson, 2003) and organizational effectiveness (Lowe et al., 1996). Given the need of today's organizations for combined assessment of quality-related aspects of performance (Quijano, Navarro, Yepes, Berger $\&$ Romeo, 2008) the importance for organizations of transformational leadership behavior (Molero et al., 2007) in wider practical and cultural contexts seems obvious. The well-known MLQ (Bass, 1985) is rather long and this makes it difficult to use in practical circumstances. Moreover, from the scientific point of view, some authors (Burchell \& Marsh, 1992) also report that refusal to participate in assessments could be influenced by the length of the questionnaire, and it thus seems necessary to have a reduced set of items to measure transformational leadership. These practical reasons can be consi- 
dered to outweigh the psychometric advantages of a longer scale (Muck, Hell \& Gosling, 2007).

\section{Mixed empirical support for the transformational leadership model as developed by Bass $(1985,1995)$}

Despite the effectiveness of transformational leadership its proposed structure has proved highly controversial (e.g., Deluga \& Souza, 1991; Rafferty \& Griffin, 2004; Tejeda et al., 2001; Tepper \& Percy, 1994; Tracey \& Hinkin, 1998). Past research on transformational leadership placed the emphasis on a more differentiated model of this style of leadership (Bass \& Avolio, 1995), although high correlations between the transformational scales have often been addressed in the literature (Avolio et al., 1999; Bycio et al., 1995; Carless, 1998; Den Hartog, Van Muijen \& Koopman, 1997).

As a result of the mixed empirical support for a differentiated transformational model, authors such as Carless (1998) and Tepper and Percy (1994) have argued that research should examine the higher-order factors of transformational leadership rather than the individual components of the model. Given this mixed empirical support for the four-factor-model of transformational leadership it is worth investigating its structure when using the concept for performance-related assessment.

\section{Overview of the present study}

Taking these findings into account the objective of the present study was to clarify empirically the evidence for the validity of the Spanish version of the short scale for transformational leadership (short HSA-TFL-ES) developed as part of the Human System Audit framework (Quijano et al., 2008). Evidence of validity was based on different sources. First, to analyze convergent validity, we compared the short HSA-TFL to the MLQ. Secondly, we analyzed the dimensionality of the scale by conducting an exploratory factor analysis using a Spanish sample. To confirm the structure of the scale, confirmatory factor analysis was applied using three samples (one from the United Kingdom, one from Poland and one from Portugal). Following Den Hartog, House, Hanges, Ruiz-Quintanilla and Dorfman (1999) we expect for the HSA-TFL short scale for transformation leadership a universal construct across cultures. The criterion validity of this short HSA-TFL was subsequently assessed using subjective criteria variables (satisfaction, commitment and identification). In line with the results of other studies (Bycio et al., 1995; Lowe et al., 1996; Nemanicha \& Seller, 2007; Podsakoff et al., 1990) our hypothesis is that transformational leadership is positively related in all four european countries to satisfaction, commitment and identification. We also based evidence for validity on internal consistency.

\section{Methods}

\section{Participants}

Data were collected from four samples. The first sample, which was used for exploratory factor analysis, consisted of employees from a mediumsized hospital in Spain. From a total of 1094 target participants, responses were received from 625 employees (response rate $=57.16 \%$ ). These employees assessed the transformational leadership style of their direct leader or supervisor by responding to the HSA short scale for transformational leadership. The professional occupations of these participants were distributed as follows: $17 \%$ were doctors, $28 \%$ nurses, $3.5 \%$ other qualified staff, $18.2 \%$ nursing assistants and $19 \%$ non-healthcare staff (19\%), with the remaining $12.2 \%$ not falling under any of these categories. No response was received from $2.1 \%$. Of the total, $9.9 \%$ identified themselves as managers.

For the confirmatory factor analysis we used three samples of 776 hospital workers, each one from a different european country (UK, Poland and Portugal) and comprising 50 doctors, 555 nurses and 171 other workers, all of whom responded to the short HSA-TFL questionnaire. As before, the employees assessed the transformational leadership style of their direct leader or supervisor. 
TABLE 1

Description of the samples in the countries

\begin{tabular}{lccccc}
\hline & Doctors & Nurses & Other & TOTAL & Managers* \\
\hline Spain & $106(17 \%)$ & $175(28 \%)$ & $344(55 \%)$ & 625 & $62(9.9 \%)$ \\
Portugal & - & $464(89.2 \%)$ & $56(10.8 \%)$ & 520 & $56(10.8 \%)$ \\
Poland & $37(24 \%)$ & $56(36.4 \%)$ & $61(39.6 \%)$ & 154 & $11(7.1 \%)$ \\
United Kingdom & $13(12.7 \%)$ & $35(34.3 \%)$ & $54(52.9 \%)$ & 102 & $59(57.8 \%)$ \\
TOTAL & 156 & 730 & 515 & 1401 & $188(7.5 \%)$ \\
\hline
\end{tabular}

* Number and percentage of TOTAL. Source: Own work.

\section{Measures}

\section{Transformational leadership}

The Human System Audit short scale for transformational leadership (HSA-TFL-ES)

The transformational leadership short scale (HSATFL-ES) was developed as part of the Human System Audit (Quijano et al., 2008) framework for quality related assessment of human resources and processes. It is designed to evaluate participants' perceptions of their supervisors' transformational leadership. The items reflect charisma, inspirational motivation, intellectual stimulation and individualized consideration. The short HSATFL-ES was developed from the long version of the HSA-TFL-ES using principles such as semantic heterogeneity of the items, content validity, and a high level of explained variance of the items as regards the conceptual dimensions. The content validity of the Spanish version of the short-scale was considered adequate. A panel of five expert judges with extensive active research and applied content experience judged the selected items at the beginning of the development process. The applied scale consists of eight items, with two for each sub-dimension. The items are rated on a 5-point Likert scale ranging from $0(=$ definitely do not agree) to 4 (= frequently, most of the time, completely agree). The scale is also available in Polish, Portuguese and English versions, which were developed through a careful process of translation and back-translation into Portuguese, English and Polish by native speakers who were experts in the field of organizational psychology. The content experts in each culture did not see a reason to modify or add items to the existing Spanish version.

Multifactor Leadership Questionnaire MLQ (5X) Spanish version

In order to test the convergent validity of the leadership instrument (the Spanish version of the HSA-TFL) we used the subordinates' version of the Spanish Multifactor Leadership Questionnaire MLQ (5X), validated by Molero (1994). This comprises questions that are specifically phrased for subordinates to evaluate their leader, and items are scored on a Likert-type scale from $0=$ definitely not to $4=$ frequently, most of the time.

\section{Subjective criteria}

The study included three subjective measures that were used to analyze the criterion validity of the HSA-TFL-ES. Respondents were asked to rate their identification with the organization, their organizational commitment (Identification/commitment Inventory ICI) and their satisfaction with the leader and the organization. These scales ranged from 1 (= definitely do not agree) to 5 (= completely agree) in all four participating countries. The items for the subjective criteria were again translated and back- 
translated by native speakers, who were experts in the field of organizational psychology.

\section{Identification/Commitment Inventory} (HSA-ICI)

The questionnaires for organizational commitment and identification were developed by Quijano, Navarro and Cornejo (2000). The scale for Organizational Commitment (OC) is based on the concepts of Meyer and Allen (1991) and Mael and Ashforth (1992). The inventory represents a holistic model of OC, integrating attitudinal and behavioral perspectives. Organizational Identification (OI) is conceptually based on the ideas of O'Reilly and Chatman (1986), Franklin (1975) and Mael and Ashforth (1992). OI is considered as a type of link between employees and organization, which implies cognition, affect and desire. The questionnaire consists of twenty items. Its development and good psychometric properties (Cronbach's Alpha of 0.941) are described by Romeo, Yepes, Berger, Guàrdia, and Castro (2011).

\section{Satisfaction Inventory (HSA-SI)}

The satisfaction scale was developed by Yepes-Baldó, Romeo, Berger, Díaz de Quijano, and GómezBenito (under revision). It is based on the concepts of Meliá and Peiró (1989) and Meliá, Peiró, and Calatayud (1986). It comprises eight items that cover satisfaction with the support and recognition of superiors, with the relationship with colleagues, with learning and professional development, with the physical working conditions, with job security and stability as regards the future, and, finally, satisfaction with salary and social benefits. The scale presents with an alpha of Cronbach of $0.0771 \mathrm{a}$ good internal consistency, similar to that obtained by the abovementioned and other authors (Hunt, Osborn \& Schuler, 1978; Schriesheim, 1979; Schriesheim, Kinicki \& Schriesheim, 1979), as well as good validity. One factor is explaining $38.86 \%$ of the variance. The scales' concept and psychometric properties are reported by YepesBaldó et al. (under revision).

\section{Procedure}

The questionnaires were administered to employees of hospitals in Spain, Portugal, the United Kingdom and Poland over a two-week period. Full anonymity was assured and participants answered voluntarily. Once completed the questionnaires were returned directly to the researchers.

\section{Statistical Analysis}

To analyze the convergent validity of the short HSA-TFL-ES the MLQ was used to correlate the short HSA-TFL-ES with the Spanish version of the Multifactor Leadership Questionnaire (MLQ-5X). The convergent validity of the short HSA-TFL-ES was also assessed by testing both scales for any differences between the means of the composite scores of transformational leadership, using the MLQ and the short HSA-TFL-ES in a Spanish sample of 105 hospital workers. Results were compared using the Wilcoxon signed-rank test for paired samples, which was chosen because the distribution of scores for the HSA short-scale did not follow a normal curve and the data are ordinal.

To explore the structure of the HSA-TFL-ES an exploratory factor analysis with a Spanish sample of 625 hospital workers was conducted. To assess the adequacy of the sample the Kaiser-Meyer-Olkin index (KMO) and Bartlett's test of sphericity (BTS) were calculated. The principal components extraction method was used to identify the factors that explained the most variance and correlations. The following criteria were established: $\mathrm{KMO}$ should be greater than 0.5; BTS was set at $p<0.05$; the item loadings should be greater than 0.40 ; the explained variance of the first factor should be more than $40 \%$; and the item-scale correlation should be more than 0.35 .

To test the explored structure and the factor validity of the leadership instrument, a confirmatory factor analysis (CFA) was conducted with a further sample of 776 hospital workers from Portugal, the United Kingdom and Poland. This CFA was performed using the LISREL program, version 8.6 (Jöreskog \& Sörbom, 2006a) in order to test whether the 
data supported a factor structure of four factors, or one general factor as explored in the exploratory factor analysis. The weighted least squares (WLS) method was used for estimation, as recommended by Jöreskog and Aish (1993) for ordinal data. In a previous step, covariance matrices and asymptotic covariance matrices were obtained by using Prelis 2, version 2.50 (Jöreskog \& Sörbom, 2006b). Following the recommendations of Kaplan (2000) and MacCallum and Austin (2000), various alternative criteria were used to evaluate the model's overall goodness of fit. The following indices were used: a) $\chi^{2}$ likelihood ratio statistic; b) root mean square error of approximation (RMSEA) and its corresponding $90 \%$ confidence intervals; c) goodness of fit index (GFI); d) non-normed fit index (NNFI); and e) comparative fit index (CFI). Indicators of a good fit are that $\chi^{2}$ is not significant; that the GFI, NNFI and CFI have values above 0.90; and that the RMSEA value does not exceed 0.08.

To analyze the criterion validity of the HSATFL-ES its relationship with the subjective performance criteria was studied using a correlation design. Subordinates from all four countries were asked to rate the following subjective performance indicators: organizational commitment, organizational identification and satisfaction. The hypothesis that the HSA-TFL is positively related to subjective performance in different countries was tested.

Internal consistency was evaluated as a measure of the reliability of the HSA-TFL-ES. This was done by calculating Cronbach's alpha, which was considered to be the optimal method for determining the internal consistency as it takes into account the degree of covariance between the test items. The following criterion was established: the value of Cronbach's alpha should be at least 0.8. This analysis was performed with 625 Spanish hospital workers.

\section{Results}

\section{Dimensionality}

The short HSA-TFL-ES was first studied through exploratory factor analysis, and we therefore used the items as indicators. When exploring the dimensions of the leadership short scale the following results were obtained for the Spanish sample: adequacy of the data for factor analysis was high, with a Kaiser-Meyer-Olkin index of 0.936 and Bartlett's test of sphericity $=4005.127(p<0.001)$. Loadings between 0.822 and 0.890 indicated that all the items were good indicators of the construct. Principal components analysis yielded one factor, which explained $72.78 \%$ of the variance. The scree plot confirmed a one-factor solution, as well as the high item inter-correlations and item-scale correlations (see Table 2).

The next step involved testing whether the unidimensionality found in the spanish sample would be replicated in the three other european samples, comparing a one-factor with a four-factor model. The factor loadings were all significant $(p<0.01)$ and notably high, thus illustrating the relevance of the corresponding item in measuring the construct and indicating that the chosen indicators provide a reliable measure of it. With respect to fit indices the values were as follows: $\chi^{2}(20)=267.63, p<$ 0.01; $\operatorname{RMSEA}=0.08(\mathrm{CI}=0.07-0.09) ; \mathrm{GFI}=$ 0.99; NNFI $=0.97$; $\mathrm{CFI}=0.98$. All the fit indices, apart from $\chi^{2}$, reached the values established as satisfactory, since the RMSEA is 0.08 and the GFI, NNFI and CFI are all above 0.95. Given the large sample size used in this study, the $\chi^{2}$ value may lead to the rejection of acceptable models due to excessive power (Hayduk, 1996); therefore, we rely only on the alternative fit indices.

We also tested whether the structure of a fourfactor model as proposed by Bass could be confirmed. However, the four-factor model presents some Heywood cases, with two correlations greater than 1 between factors. This led us to propose a more complex model that maintains the four factors and also specifies a second-order factor that is subject to the four primary factors. However, we obtained the same results with this second model: the fit indices reached good values but the model still presented some Heywood cases, this time with two standardized gamma values greater than $1 \mathrm{~s}$. These findings led us to accept the unidimensional model as the best representation of the data. 
TABLE 2

Factor loadings means, standard deviations, intercorrelations and item-scale correlation for the items of the HSATFL-ES at individual level

\begin{tabular}{|c|c|c|c|c|c|c|c|c|c|c|c|c|}
\hline & $\begin{array}{l}\text { Factor } \\
\text { loading }\end{array}$ & Mean & $S D$ & I1 & $\mathrm{I} 2$ & I3 & I4 & I5 & I6 & I7 & I8 & $\begin{array}{l}\text { Item- } \\
\text { scale } \\
\text { correlation }\end{array}$ \\
\hline I1 & 0.832 & 3.28 & 1.047 & 1.000 & & & & & & & & 0.779 \\
\hline I2 & 0.859 & 2.77 & 1.091 & $0.709 * *$ & 1.000 & & & & & & & 0.812 \\
\hline I3 & 0.855 & 3.17 & 1.004 & $0.707 * *$ & $0.708 * *$ & 1.000 & & & & & & 0.806 \\
\hline I4 & 0.822 & 2.94 & 1.114 & $0.611 * *$ & $0.672 * *$ & $0.625 * *$ & 1.000 & & & & & 0.767 \\
\hline I5 & 0.846 & 3.06 & 1.062 & $0.652 * *$ & $0.674 * *$ & $0.656 * *$ & $0.718 * *$ & 1.000 & & & & 0.797 \\
\hline I6 & 0.851 & 3.07 & 1.031 & $0.629 * *$ & $0.642 * *$ & $0.677 * *$ & $0.647 * *$ & $0.684 * *$ & 1.000 & & & 0.801 \\
\hline I7 & 0.867 & 3.02 & 1.046 & $0.659 * *$ & $0.665 * *$ & $0.675 * *$ & $0.650 * *$ & $0.676^{* *}$ & $0.808^{* *}$ & 1.000 & & 0.820 \\
\hline I8 & 0.890 & 2.76 & 1.053 & $0.669 * *$ & $0.785 * *$ & $0.737 * *$ & $0.694 * *$ & $0.705^{* *}$ & $0.708^{* *}$ & $0.758 * *$ & 1.000 & 0.851 \\
\hline
\end{tabular}

Source: Own work

\section{Relationships with other variables}

The high correlation between the HSA-TFL-ES and the MLQ $(5 X)(r=0.84, p<0.001)$ supports the convergent validity between these constructs. Additionally, the comparison of average transformational leadership scores as measured by the HSA-TFL-ES and the MLQ reveals that MLQ scores $(X=1.91)$ were almost equal to the average transformational leadership scores as measured by the HSA-TFL-ES $(X=1.92)$ (both scale measures between 0 and 4). The Wilcoxon signed-rank test revealed no significant differences between the average ratings of transformational leadership as measured by the MLQ and the HSA short-scale $(z=-2.84, p>0.05$, n.s.). Table 3 shows that the transformational leadership style measured by the short HSA-TFLES was significantly associated with subjective performance (organizational commitment, organizational identification and satisfaction) in all countries.

\section{TABLE 3}

Correlations for leadership and subjective performance indicators

\begin{tabular}{lcccc}
\hline & $\begin{array}{c}\text { Leader- } \\
\text { ship } \\
\text { Spain }\end{array}$ & $\begin{array}{c}\text { Leader- } \\
\text { ship } \\
\text { Portugal }\end{array}$ & $\begin{array}{c}\text { Leader- } \\
\text { ship } \\
\text { Poland }\end{array}$ & $\begin{array}{c}\text { Leader- } \\
\text { ship } \\
\text { U. King- } \\
\text { dom }\end{array}$ \\
\hline $\begin{array}{l}\text { Identifica- } \\
\text { tion }\end{array}$ & $0.515 * *$ & $0.328 * *$ & $0.507 * *$ & $0.351 * *$ \\
Commitment & $0.599 * *$ & $0.305 * *$ & $0.562 * *$ & $0.323 * *$ \\
Satisfaction & $0.666^{* *}$ & $0.500 * *$ & $0.630 * *$ & $0.635^{* *}$ \\
MLQ & $0.840 * *$ & & & \\
\hline$* * 00.01$ (bilateral). Source: Own work. &
\end{tabular}

\section{Internal consistency}

In order to evaluate the internal consistency, Cronbach's alpha was calculated for the HSATFL-ES. The instrument shows satisfactory alpha levels (Cronbach's alpha $=0.946$, item-scale 
correlation between 0.767 and 0.851 ) and we therefore assume that our results are based on reliable construct assessment.

\section{Discussion}

Although the MLQ is well known and often applied, it is too long to use in combined assessments. Therefore, a short scale for transformational leadership, based on the concept of Bass, was developed and tested. This study provides evidence for the convergent validity between the short HSA-TFL-ES and the MLQ. The results revealed a one-factor structure for the transformational leadership concept, as measured by the short HSA-TFL-ES. Furthermore, the results regarding criterion validity show that it is positively related to relevant subjective criterion variables across four nations.

\section{Implications for theory}

The results indicate that the short HSA-TFL-ES is a stable, valid and robust instrument, aspects which are important since they bring vigor to research and make the results obtained more interpretable. Although our empirical results suggest that the MLQ and the HSA-TFL-ES are highly convergent, they do show their own structure of the transformational leadership concept. The short HSA-TFL-ES appears to measure transformational leadership qualities with a unidimensional concept. Furthermore, whereas the MLQ enquires directly about the leader's behavior, the short HSA-TFLES asks much more for the impact that the leader's behavior has on the follower. This may account for the unidimensional structure of the HSA-TFL-ES, establishing the hypothesis that all transformational leadership behavior leads to follower processes. The confirmation of the unidimensionality of the HSA-TFL-ES might satisfy the need expressed by Felfe (2006) for further development of survey instruments, especially as regards newly created items, optimized scales and a simplified factor structure of the transformational leadership concept. Both approaches are related to subjective performance criteria. The short HSA-TFL-ES is notably related to relevant criterion variables across four nations, specifically commitment, identification and satisfaction. In sum, these analyses lend further support to the validity of the HSA-TFL-ES short scale.

\section{Implications for practice}

Given the needs of today's organizations it seems necessary to bridge the gap between scientific research and practice in the organizational context (Murphy \& Saal, 1990). For example, the European Foundation for Quality Management (EFQM, 2000) is dedicated to the development of organizational excellence and identifies leadership as one of its main concerns. This means that today's organizations often need to fulfil quality requirements and, therefore, they need to combine the assessment of several human processes (Quijano et al., under revision) with the assessment of leadership and quality-related aspects of performance. Meeting these needs requires the development of instruments that are quick to apply (Carless et al., 2000), short (Burchell \& Marsh, 1992) and based on scientific research (Felfe, 2006). The wellknown MLQ (Bass, 1985) is rather long and this makes it difficult to use in practical circumstances. Some researchers have used a reduced set of items to measure transformational leadership (e.g. Tejeda et al., 2001), but as Rafferty and Griffin (2004) point out, this strategy has been driven by empirical results and has not been accompanied by a strong theoretical approach to explain the allocation of items to factors. They argue that it is important to adopt a theoretically driven approach when evaluating the sub-dimensions of transformational leadership. Overall, the theoretical debate and empirical results suggest that due to its relevance to today's organizations the concept of transformational leadership should be assessable in broader practical and cultural contexts; this would be achieved by using a concept-based and valid short scale that can be combined with the assessment of other organizational and human processes.

The present results have implications for organizational assessment and intervention in these wider practical and cultural contexts. Indeed, ob- 
taining an easy-to-apply, valid short instrument that measures transformational leadership goes some way to meeting the needs of enterprises for combined assessment of leadership and qualityrelated aspects of performance.

The unidimensionality of the construct could imply that all of the four sub-dimensions must be present for a leader to show transformational leadership. This has implications for the development of leadership in organizations, where this is a coveted quality. In this regard, an integrated leadership development program targeting all four dimensions with the same importance could be interesting.

The impact of transformational leadership as measured by the HSA-TFL-ES on subjective performance criteria such as satisfaction, identification and commitment has implications for the assessment and development of transformational leadership behavior, helping enterprises to accomplish their business goals or to manage change and improvement processes.

\section{Limitations}

The study has a number of limitations. Firstly, the analyzed samples correspond exclusively to the healthcare field and the results obtained may therefore be specific to this context.

Secondly, all measures administered were selfreported surveys. This opens up a potential problem of source bias. It can be estimated that this inflated the results in about $26 \%$ (Doty \& Glick, 1998; Spector, 2006). Even if this is the case, as can be seen in table 3, considerable results still could be found.

Thirdly, we only used positive subjective performance criteria and did not include objective performance criteria or negative criteria so as to avoid common method variance (Avolio, Yammarino \& Bass, 1991). Although other studies (Barling et al., 1996; Geyer \& Steyrer, 1998; Rowold \& Heinitz, 2007) showed an impact of TFL on objective performance criteria, it cannot be ruled out that the use of objective and negative criteria would lead to different results.
Fourthly, the subjective performance criteria used are limited and, therefore, provide limited information about the impact of transformational leadership as measured by the HSA-TFL-ES on subjective performance. Further subjective criteria such as extra-effort and effectiveness (Hetland \& Sandal, 2003; Rowold \& Heinitz, 2007) could produce a wider range of information about this aspect.

Fifthly, performance could be influenced by additional variables. Furthermore, context variables such as management systems or the structure of the organization may influence performance (Fuller et al., 1996; Lowe et al., 1996; Rowold \& Heinitz, 2007). Thus, we cannot be sure about the extent to which leadership behavior and/or other variables contribute to performance.

Sixthly, these studies focus on followers' ratings. In practical terms it would be interesting in the future to compare followers' ratings and leaders' self-ratings in a $360^{\circ}$ feedback. Finally, TFL was measured at the same point of time, whereas longitudinal studies could better identify the possible relationship between TFL and subjective performance criteria.

\section{Perspectives for future research}

As these results were obtained in a healthcare sample, additional studies should be conducted to validate the instrument further in a different context.

Future research with the short HSA-TFL questionnaire should use hard performance criteria and unrequested outcomes such as absenteeism or experienced stress. It should also implement divergent measures in interview and observation so as to determine more clearly the criterion validity and obtain greater insight into the relationship between transformational leadership and performance. Relevant controls e.g., positive appraisal of leaders should be taken into account in future research.

The role of context variables, such as structure, should be explored in future studies to understand better their impact on performance.

The structure of the HSA-TFL construct should be analyzed using samples from other sec- 
tors so as to clarify whether the results are specific for the healthcare sector.

Cross-cultural comparison analysis should be done with regard to factor structure stability. To get a deeper insight the factor structure of the HSATFL short should be compared cross-culturally to the MLQs factor structure.

\section{References}

Avolio, B. J., Bass, B. M. \& Jung, D. I. (1999). Reexamining the components of transformational and transactional leadership using the Multifactor Leadership Questionnaire. Journal of Occupational and Organizational Psychology, 72, 441-462.

Avolio, B. J., Yammarino, F. J. \& Bass, B. M. (1991). Identifying common method variance with data collected from a single source: An unresolved sticky issue. Journal of Management, 17, 571-587.

Barling, J., Weber, T. \& Kelloway, E. K. (1996). Effects of transformational leadership training on attitudinal and financial outcomes: A field experiment. Journal of Applied Psychology, 81, 827-832.

Bass, B. M. (1985). Leadership beyond expectations. New York: Free Press.

Bass, B. M. \& Avolio, B. J. (1995). MLQ Multifactor leadership Questionnaire (Technical Report). Redwood City, CA: Mind Garden.

Bass, B. M., Avolio, B. J., Jung, D. I. \& Berson, Y. (2003). Predicting unit performance by assessing transformational and transactional leadership. Journal of Applied Psychology, 88, 207-218.

Burchell, B. \& Marsh, C. (1992). The effect of questionnaire length on survey response. Quality and Quantity, 26, 233-244.

Burns, J. M. (1978). Leadership. New York: Harper and Row, Publishers.

Bycio, P., Hackett, R. D. \& Allen, J. S. (1995). Further assessments of Bass's (1985) conceptualization of transactional and transformational leadership. Journal of Applied Psychology, 80 (4), 468-478.

Carless, S. A. (1998). Assessing the discriminant validity of transformational leader behaviour as measured by the MLQ. Journal of Occupational and Organisational Psychology, 7, 353-358.
Carless, S. A., Wearing, A. J. \& Mann, L. (2000). A short measure of transformational leadership. Journal of Business and Psychology, 14 (3), 389-405.

Deluga, R. \& Souza, J. (1991). The effects of transformational and transactional leadership styles on the influencing behavior of subordinate police officers. Joumal of Occupational Psychology, 64, 49-55.

Den Hartog, D. N., House, R. J., Hanges, P. J., RuizQuintanilla, S. A. \& Dorfman, P. W. (1999). Culture specific and cross-culturally generalizable implicit leadership theories: Are attributes of charismatic/transformational leadership universally endorsed? Leadership Quarterly, 10 (2), 219-239.

Den Hartog, D. N., Muijen, J. J. \& Koopman, P. L. (1997). Transactional versus transformational leadership: An analysis of the MLQ. Journal of Occupational and Organizational Psychology, 70, 19-34.

Doty, D. H. \& Glick, W. H. (1998). Common methods bias: Does common methods variance really bias results? Organizational Research Methods, 1, 374 406.

Dumdum, U. R., Lowe, K. B. \& Avolio, B. J. (2002). A meta-analysis of transformational and transactional leadership correlates of effectiveness and satisfaction: An update and extension. In B. J. Avolio \& F. J. Yammarino (Eds.), Transformational and charismatic leadership: The road ahead (pp. 35. 66). Amsterdam: JAI.

European Foundation for Quality Management. (2000). Introducing excellence. Got the10th of April, 2006 in www.efqm.org

Felfe, J. (2006). Transformationale und charismatische Führung-Stand der Forschung und aktuelle Entwicklungen [Transformational and charismatic leadership: State of research and perspectives]. Zeitschrift für Personalpsychologie, 5, 163-176.

Franklin, J. L. (1975). Power and commitment-empirical assessment. Human Relations, 28 (8), 737-753.

Fuller, J. B., Patterson, C. E. P., Hester, K. \& Stringer, D. Y. (1996). A quantitative review of research on charismatic leadership. Psychological Reports, 78, 271-287.

Geyer, A. L. J. \& Steyrer, J. M. (1998). Transformational leadership and objective performance in banks. 
Applied Psychology: An International Review, 47, 397-420.

Hayduk, L. A. (1996). LISREL issues, debates, and strategies. Baltimore: Johns Hopkins University Press.

Hetland, H. \& Sandal, G. M. (2003). Transformational leadership in Norway: Outcomes and personality correlates. European Journal of Work and Organizational Psychology, 12 (2), 147-170.

Hunt, J. G., Osborn, R. N. \& Schuler, R. S. (1978). Relations of discretionary and non discretionary leadership to performance and satisfaction in a complex organization. Human Relations, 31, 507-523.

Jöreskog, K. G. \& Aish, A. M. (1993). Structural equation modeling with ordinal variables. Chicago, IL: Scientific Software, Inc.

Jöreskog, K. \& Sörbom, D. (2006a). LISREL 8.8 for Windows [Computer Software]. Lincolnwood, IL: Scientific Software International, Inc.

Jöreskog, K. \& Sörbom, D. (2006 b). PRELIS 2.50 for Windows [Computer Software]. Lincolnwood, IL: Scientific Software International, Inc.

Judge, T. A. \& Piccolo, R. F. (2004). Transformational and transactional leadership: A meta-analytic test of their relative validity. Journal of Applied Psychology, 89, 755-768.

Jung, D. I., Chow, C. \& Wu, A. (2003). The role of transformational leadership in enhancing organizational innovation: Hypotheses and some preliminary findings. Leadership Quarterly, 14, 525-544.

Kaplan, D. (2000). Structural equation modeling. Foundations and extensions. Thousand Oaks: Sage.

Lowe, K. B., Kroeck, K. G. \& Sivasubramaniam, N. (1996). Effectiveness correlates of transformation and transactional leadership: A meta-analytic review of the MLQ literature. Leadership Quarterly, 7, 385-425.

Nemanich, L. A. \& Keller, R. T. (2007). Transformational leadership in an acquisition: A field study of employees. Leadership Quarterly, 18, 49-68.

MacCallum, R. C. \& Austin, J. T. (2000). Applications of structural equation modeling in psychological research. Annual Review of Psychology, 51, 201-226.

Mael, F. \& Ashforth, B. E. (1992). Alumni and their alma mater: A partial test of the reformulated model of organizational identification. Journal of Organizational Behaviour, 13, 103-123.
Meliá, J. L. \& Peiró, J. M. (1989). El cuestionario de satisfacción S10/12. Estructura factorial, fiabilidad y validez. Psicología del Trabajo y de las Organizaciones, 11, 179-185.

Meliá, J. L., Peiró, J. M. \& Calatayud, C. (1986). El cuestionario general de satisfacción en organizaciones laborales. Estudios factoriales, fiabilidad y validez (Presentación del cuestionario S4/82). Millars, 9, 43-77.

Meyer, J. P. \& Allen, N. (1991). A three-component conceptualization of organizational commitment. Human Resource Management Review, 1 (1), 61-89.

Molero, F. (1994). Carisma y liderazgo carismático: una aproximación empírica desde las perspectivas de Bass y Friedman. Tesis doctoral no publicada, UNED, Madrid, España.

Molero, F., Cuadrado, I., Navas, M. \& Morales, J. F. (2007). Relations and effects of transformational leadership: A comparative analysis with traditional leadership styles. The Spanish Journal of Psychology, 10 (2), 358-368.

Muck, P. M., Hell, B. \& Gosling, S. D. (2007). Construct validation of a short five-factor model instrument. A self-peer study on the German adaptation of the Ten-Item Personality Inventory (TIPI-G). European Journal of Psychological Assessment, 3, 166-175.

Murphy, K. R. \& Saal, F. E. (1990). Introduction. In K. R. Murphy \& F. E. Saal (Eds.), Psychology in organizations: Integrating science and practice (pp. 1-4). Hillsdale, NJ: Lawrence Erlbaum Associates.

O'Reilly, C. \& Chatman, J. (1986). Organizational commitment and psychological attachment: The effects of compliance, identification and internalization on prosocial behavior. Journal of Applied Psychology, 71 (3), 492-499.

Podsakoff, P. M., MacKenzie, S. B., Moorman, R. H. \& Fetter, R. (1990). Transformational leader behaviors and their effects on followers' trust in leader, satisfaction and organizational citizenship behaviors. Leadership Quarterly, 1, 107-142.

Quijano, S., Navarro, J. \& Cornejo, J. M. (2000). Un modelo integrado de compromiso e identificación con la organización: análisis del cuestionario ASH-ICI. Revista de Psicología Social Aplicada, 10 (2), 27-61. 
Quijano, S. (Eds.). (2006). Dirección de recursos humanos y consultoría en las organizaciones: el ASH (Auditoría del Sistema Humano). Barcelona: Icaria.

Quijano, S., Navarro, J., Yepes, M., Berger, R. \& Romeo, M. (2008). La Auditoría del Sistema Humano (ASH) para el análisis del comportamiento humano en las organizaciones. Papeles del Psicólogo, 29, 92-106.

Rafferty, A. E. \& Griffin, M. A. (2004). Dimensions of transformational leadership: Conceptual and empirical extensions. Leadership Quarterly, 15, $329-354$.

Romeo, M., Yepes, M., Berger, R., Guàrdia, J. \& Castro, C. (2011). Identification-Commitment Inventory (ICI Model): Confirmatory factor analysis and construct validity. Quality and Quantity, 45 (4), 901-909.

Rowold, J. \& Heinitz, K. (2007). Transformational and charismatic leadership: Assessing the convergent, divergent and criterion validity of the MLQ and the CKS. Leadership Quarterly, 18, 121-133.

Schriesheim, C. A. (1979). The similarity of individualdirected and group-directed leader behaviour descriptions. Academy of Management Journal, 22, 345-355.

Schriesheim, C. A., Kinicki, A. \& Schriesheim, J. F. (1979). The effect of leniency on leader behaviour descriptions. Organizational Behavior and Human Performance, 23, 1-29.
Seltzer, J. \& Bass, B. M. (1990). Transformational leadership: Beyond initiation and consideration. Journal of Management, 16, 693-703.

Spector, P.E. (2006). Method variance in organizational research: Truth or urban legend? Organizational Research Methods, 9 (2), 221-232.

Tejeda, M. J., Scandura, T. A. \& Pillai, R. (2001). The MLQ revisited: Psychometric properties and recommendations. Leadership Quarterly, 12, 31-52.

Tepper, B. J. \& Percy, P. M. (1994). Structural validity of the Multifactor Leadership Questionnaire. Educational and Psychological Measurement, 54, 734-744.

Tracey, J. B. \& Hinkin, T. R. (1998). Transformational leadership or effective managerial practices? Group and Organization Management, 23 (3), 220-236.

Yammarino, F. J., Spangler, W. D. \& Bass, B. M. (1993). Transformational leadership and performance: A longitudinal investigation. Leadership Quarterly, 4 (1), 81- 102.

Yepes-Baldó, M., Romeo, M. Berger, R., Díaz de Quijano, S. \& Gómez-Benito, J. (under revision). Development and Validation of the Psychological Human Capital Questionnaire (PHCQ).

Zhu, W., Chew, I. K. H. \& Spangler, W. D. (2005). CEO transformational leadership and organizational outcomes: The mediating role of human-capitalenhancing human resource management. Leadership Quarterly, 16, 39-52. 